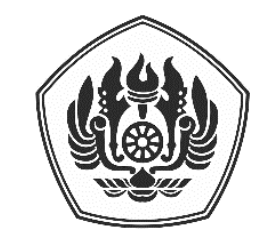

Padjadjaran Journal of International Law

ISSN: 2549-2152, EISSN: 2549-1296

Volume 4, Number 2, June 2020

\title{
Impact of Philippines' Withdrawal from International Criminal Court on Crime Against Humanity Investigation in Philippines
}

\author{
Aisyah Jasmine Yogaswara*
}

\begin{abstract}
Rodrigo Roa Duterte is the incumbent president of the Philippines who was inaugurated on June 30th 2016 and initiated the War on Drugs Operation to eradicate drug abuse in the Philippines one day after his inauguration. The operation gave authorization to the members of Philippines National Police to 'neutralize' or kill suspects of illegal drugs dealers and users. The operation also related to other crime such as rape, imprisonment, and torture. The crimes are committed as part of a widespread and systematic attack directed against the civilian population as therefore it can be qualified as crimes against humanity. Philippines' status as a state party to Rome Statute gives ICC the chance to prosecute Philippines' nationals if they committed crimes against humanity. However, after the ICC Prosecutor initiated preliminary examination on the related case, Philippines deposited its instrument of withdrawal from the Rome Statute. The purpose of this research is to find out the legal effect of Philippines withdrawal toward ICC's process of preliminary examination, investigation, and trial, and whether ICC have any jurisdiction over crimes against humanity that is committed after Philippines' withdrawal becomes effective.
\end{abstract}

Keywords: Crimes Against Humanity, International Criminal Court, Rome Statute

\section{Dampak Penarikan Diri Filipina dari Keanggotaan Mahkamah Pidana Internasional Terhadap Investigasi Kejahatan Terhadap Kemanusiaan di Filipina}

\begin{abstract}
Abstrak
Rodrigo Roa Duterte menjabat menjadi Presiden Filipina pada tanggal 30 Juni 2016 dan memulai operasi pemberantasan narkotika yang disebut War on Drugs Operation sehari setelahnya. Operasi tersebut memberikan izin bagi Polisi Nasional Filipina untuk melakukan penembakan di tempat atas tersangka pengguna dan pengedar narkotika. Selain itu, terdapat kejahatan lain terkait operasi tersebut di antaranya pemerkosaan, penyiksaan dan penahanan tanpa proses hukum. Kejahatan-kejahatan tersebut dilakukan secara meluas, sistematis dan ditujukan pada populasi sipil yang menjadikannya dapat dikualifikasikan sebagai kejahatan terhadap kemanusiaan. Status Filipina sebagai negara pihak dalam Statuta Roma menjadikan ICC memiliki kewenangan untuk mengadili warga negara Filipina yang melakukan kejahatan terhadap kemanusiaan. Namun, setelah Jaksa Penuntut ICC memulai pemeriksaan pendahuluan atas War on Drugs Operation, Filipina melakukan penarikan diri dari Statuta Roma. Tujuan dari penulisan tugas akhir ini adalah untuk mengetahui bagaimana pengaruh penarikan diri Filipina dari
\end{abstract}

PADJADJARAN JOURNAL OF INTERNATIONAL LAW Volume 4 Issue 2 Year 2020 [ISSN 2549-2152] [e-ISSN 2549-1296]

Post-graduate Student at Faculty of Law, Universitas Indonesia, Jalan Margonda Raya, Beji, Depok, 16424, aisyahjasminey@gmail.com 
Impact of Philippines' Withdrawal from International Criminal Court on Crime Against

Humanity Investigation in Philippines

Statuta Roma terhadap pemeriksaan pendahuluan yang sedang dilakukan dan apakah ICC memiliki yurisdiksi atas kejahatan terhadap kemanusiaan yang masih terjadi di Filipina pasca penarikan dirinya berlaku efektif.

Kata kunci: Kejahatan Terhadap Kemanusiaan, Mahkamah Pidana Internasional, Statuta Roma

\section{A. INTRODUCTION}

International treaties as a source of international law could be defined as a written agreement in which the state involved legally binds itself to perform certain actions or to regulate certain relations between the countries involved. ${ }^{1}$ Prof. Mochtar Kusumaatmadja defines international treaties as agreements that are entered into between members of nations with the purpose of causing certain legal impact. ${ }^{2}$ International legal subjects entering international treaties are legally bound to the principles of international treaties, namely the principles of free consent, good faith, pacta sunt servanda and pacta tertiis nec nocent nec prosunt.

However, every legal subject that is a party bound by an international treaty has the right to withdraw or terminate the agreement entered. The term withdrawal is used in multilateral agreements, and such withdrawal does not invalidate the agreement for other parties on the agreement. Meanwhile, in a bilateral agreement, the term commonly used is the termination, because when one party wishes to terminate the agreement, the agreement ends and the other party is no longer bound to the agreement. termination is defined as the release of the party of the international agreement of every obligations derived for the international treaty entered. ${ }^{3}$

International treaties could be the instrument for the establishment of an international organization that has its own legal standing and/ or its legal personality. ${ }^{4}$ The Rome Statute is an international treaty which forms the basis of the International Criminal Court (hereafter referred as ICC)'s founding instrument. ICC is a permanent international criminal justice body, which has the power to exercise jurisdiction over a person who has committed serious crimes condemned by the international community (the most serious crimes of concern to the international community) as a whole. ${ }^{5}$ ICC was established under the Rome Statute of 1998 ( hereinafter referred as the Rome Statute) which was the result of the diplomatic conference which took place in Rome on 15 - 17 July $1998 .^{6}$ The conference was attended by representatives of each country member of the United Nations or representatives from government organizations and nongovernmental organizations. After being regulated in the Rome Statute in 1998 and the provisions thereof, ICC has legally been established as a permanent international judicial body with its duties, functions, and powers domiciled in The Hague, Netherlands. ${ }^{7}$

The membership of the ICC is bear by the ratification of Rome Statute and based

Article 38 (1) of Statute of the International Court of Justice

Mochtar Kusumaatmadja dan Etty R. Agoes, Pengantar Hukum Internasional, Bandung: PT. Alumni, 2003, p. 117.

UN Handbook on Final Clause of Multilateral Treaties, p. 114.

Stephen Bouwhuis, "The International Law Commission's Definition of International Organizations", International Organizations Law Review, Vol. 9, No. 2, 2012, p. 451.

Sri Setianingsih Suwardi, "Beberapa Catatan Mahkamah Pidana Internasional (International Criminal Court) Dalam Kaitannya dengan Perserikatan Bangsa- Bangsa (PBB)", Jurnal Hukum dan Pembangunan, No. 4, Tahun 2017, p. 447

Indah Sari, "Kejahatan-Kejahatan Internasional (International Criminal Law) Dan Peranan International Criminal Court (ICC) Dalam Penegakan Hukum Pidana Internasional”, Jurnal Ilmiah Hukum Dirgantara - Fakultas Hukum - Universitas Suryadarma, Vol. 6, No. 1, 2015, p. 51

lbid. 
on Article 12 of Rome Statute, when a country ratify the statute, it become the member of the ICC and by that, accepts the jurisdiction of the Court with respect to the crimes that falls within the jurisdiction of ICC; a) the crime of genocide; b) crimes against humanity; c) war crimes; and d) the crime of aggression. ${ }^{8}$ As stated in Article 25 (1) Rome statute, ICC have jurisdiction over the State of which the person accused of the crime is a national.

However, as in other international treaties, the Rome Statute provides an opportunity for state parties to withdraw by providing an instrument of withdrawal with written notification addressed to the Secretary-General of the United Nations. ${ }^{9}$ Such withdrawal will take effect one year from the date the notification is received, unless there is another statement regarding the effective date of withdrawal. ${ }^{10}$

\section{B. PHILIPPINE'S CRIMES AGAINST HUMANITY CASE}

\section{War on Drugs Operation}

The Philippines is one of the countries with the highest number of narcotics abuse in Southeast Asia. The Philippines Drug Enforcement Agency (PDEA) in 2014 reported that there were 17,619 cases handled related to narcotics abuse, and $89 \%$ of them were abuse of narcotics in the form of shabu-shabu. ${ }^{11}$ In 2015, it was found that there were 25,041 cases related to narcotics, in which there was an increase of $70 \%$ from the previous year and the type of narcotics that was most widely used

Article $12 \mathrm{jo}$. Article 5 of Rome Statute.

Article 127 paragraph (1) of Rome Statute.

Ibid.

Philippine Drug Enforcement Agency 2014 Annual Report, p. 2.

12 Philippine Drug Enforcement Agency 2015 Annual Report, p. 1.

13 International Criminal Court the Office of the Prosecutor, "Report on Preliminary Examination Activity", 2018, p. 16.

14 Ibid.

15 More than 7,000 killed in the Philippines in six months, as president encourages murder. was still methamphetamine, which occupied $95.47 \%$ of the total cases in 2015. ${ }^{12}$

In 2016, the Philippines held a presidential election which was won by Rodrigo Roa Duterte. On June 30, 2016, Duterte was formally sworn in as President of the Philippines for a six year term until 2022. ${ }^{13}$ Right after Duterte's inauguration, he immediately launched a narcotics eradication program known as the War on Drugs Operation. ${ }^{14}$ As part of the operation, Duterte ordered law enforcement officials to combat any person suspected of being involved in the use and trafficking of narcotics in any way, even by carrying out murder. ${ }^{15}$

President Duterte orders members of the Philippines National Police (hereinafter referred to as PNP) to carry out on-the-spot shootings on suspected drug users and traffickers. ${ }^{16}$ There are three levels of government involvement in the War on Drugs Operation, namely: 1) tolerating, justifying, and encouraging the killing of narcotics users and traffickers, 2) fictional handcatching operations for opposing targets and shooting on the spot, and 3 ) cold-blooded murder as part of from acts of government terrorism. ${ }^{17}$

Six months after Duterte's inauguration, between 1 July until December 2016, reported that 6,000 people had been killed through the official War on Drugs Operation, either killings by the PNP, or by hitmen in connection with the operation. ${ }^{18}$

16 Veniati Sarlina, "Respon Amnesty Internasional Terhadap Pemberantasan Narkotika dan Obat Obatan Berbahaya (Narkoba) di Filipina pada Masa Rodrigo Duterte", eJournal IImu Hubungan Internasional, 2018, p. 897.

17 David T. Johnson, "Governing through Killing: The War on Drugs in the Philippines", Asian Journal of Law and Society, Vol. 5, 2018, p. 363.

18 Danilo Andres Reyes, "The Spectacle of Violence in Duterte's "War on Drugs"”, Journal of Current Southeast Asian Affairs, Vol. 35, 2016, p. 129. 
According to the PNP report, at least 38,000 people were jailed and 2,000 people died as the result of resisting arrest with the alleged drug abuse crime. The high rate of imprisonment on the other hand triggers a crisis in the prison due to excess capacity.

Within 2 years of Duterte's presidential term, there are at least 12,000 Filipino nationals who were killed with the accusation of the use and trafficking of narcotics, mistaken identity, or as additional victims in narcotics eradication operations run by the Philippines government. ${ }^{19}$ The Philippines government is admitting the 4,800 of the total number as victims of official eradication operations narcotics. $^{20}$ In late 2019, an independent non-governmental organization and the Philippines National Commission on Human Rights submitted a report which stated that the estimated number of War on Drugs Operation's victims was reaching 27,000 people. ${ }^{21}$

\section{Philippine's Membership in the ICC}

In 2000, President Joseph Estrada signed the Rome Statute but did not ratify the treaty during his presidency term..$^{22}$ In 2003, under the presidency of President Gloria Macapal Arroyo, a citizen of human rights activists filed a petition to the Philippines Supreme Court demanding Philippine's

19 Report on Preliminary Examination Activity 2018, Op. Cit., p. 16.

20 Ibid.

21 Rosanna Ocampo and Laila Matar, "Philippines: UN Action Offered a Glimpse of Hope and Justice", https://www.amnesty.org/en/latest/news/2019/08/p hilippines-un-action-offered-glimpse-hope-justice/, accessed on $11^{\text {th }}$ of January 2020.

22 Coalition for the International Criminal Court, "The Philippines' membership in the ICC comes to an end", https://www.coalitionfortheicc.org/news/20190315/ philippines-leaves-

icc\#: :text=As\%20of\%2017\%20March\%2C\%20the, and \%20the\%20crime\%20of\%20aggression, accessed on $25^{\text {th }}$ of November 2019.

23 Coalition for the International Criminal Court, "Updates on Philippines", government to ratify the Rome Statute, but the petition was not granted. ${ }^{23}$ After 11 years of a long process and under 3 different periods of presidency, Philippines ratified the Rome Statute in 2011. ${ }^{24}$ Philippines' citizens and many government actors are having a great impact of Philippine's withdrawal of Rome Statute by constantly putting pressure on the government. ${ }^{25}$

On 30 August 2011, located at the UN Office of Legal Affairs New York, the Philippines government deposited its instrument of ratification on the Rome Statute. ${ }^{26}$ The ratification entered into force on 1 November 2011, bringing the number of states parties that have ratified the Rome Statute to 117 countries. ${ }^{27}$

However, the Philippines' status as a member state in the ICC did not last for a long time. On 17 March 2018, President Duterte officially deposited the instrument of withdrawal from the Rome Statute to the Secretary General of the United Nations. ${ }^{28}$

The Philippines elaborated the reasons for its withdrawal on the withdrawal notification letter, explaining that Philippines opposes parties which is seems to be politicizing ICC and makes human rights as a weapon against the independence jurisdiction of the Philippines as a sovereign country who conducted its

http://www.iccnow.org/index.php?mod=newsdetail\& news=267\&lang=en, accessed on $1^{\text {st }}$ of April 2020.

24 Coalition for the International Criminal Court, "The Philippines' membership in the ICC comes to an end", Loc.Cit.

25 Ibid.

26 International Criminal Court, "The Philippines Becomes the 117th State to Join the Rome Statute System", https://asp.icc-

cpi.int/en_menus/asp/press\%20releases/press\%20rel eases\%202011/Pages /pr717.aspx, accessed on $1^{\text {st }}$ of December 2019.

$27 \quad$ Ibid.

28 Opinio Juris, "The Departed: Implications of the Philippines' Withdrawal from the ICC", http://opiniojuris.org/2018/04/12/the-departedimplications-of-the-philippines-withdrawal-fromtheicc/, accessed on $20^{\text {th }}$ of November 2019. 
own jurisdiction over issues, problems and the concerns that arise in the Philippines' efforts to protect its own citizens. $^{29}$

\section{ICC's Preliminary Examination of War on Drugs Operation}

The ICC Prosecutor officially announced the opening of investigation in the Philippines on February 8, 2018 based on communications and reports received regarding the alleged occurrence of crimes that fall under the jurisdiction of the ICC. ${ }^{30}$ The preliminary examination will focus on crimes committed in the Philippines for crimes that occurred since at least July 1, 2016 in the context of War on Drugs Operations which are suspected of causing the deaths of thousands of Filipino citizens accused of use or sale of narcotics. The individuals which become the main focus for this preliminary examination are Duterte as the President of the Philippines, top Philippines government officials who support the persecution of drug users and dealers, PNP officials and members, and other individuals who have committed thousands of killings in the Philippines. ${ }^{31}$

The ICC Prosecutor has previously released a statement regarding his concerns related to reports of extrajudicial killings of drug traffickers and users in the Philippines on 13 October 2016. ${ }^{32}$ The extrajudicial Killings have the possibility to fall under the jurisdiction of the ICC if carried out as part of a widespread and systematic attack directed against the civil

29 International Criminal Court the Office of the Prosecutor, Report on Preliminary Examination 2017, p. 64.

30 International Criminal Court, "Statement of the Prosecutor of the International Criminal Court, Fatou Bensouda, on opening Preliminary Examinations into the situations in the Philippines and in Venezuela", https://www.icccpi.int/Pages/item.aspx?name=18020 8-otp-stat, accessed on $25^{\text {th }}$ of November 2019. population. The ICC Prosecutor gave a stern warning to Filipino citizens who were involved in the mass violence that occurred in the Philippines, including the actions of ordering, soliciting, inciting, supporting, doing directly or contributing in any form, and emphasizing that they might be the charged on the ICC trial. ${ }^{33}$

The ICC Prosecutor emphasized that a preliminary examination is not an investigation, nevertheless a process to assess the available information to find the base on whether there is an acceptable basis for the ICC Prosecutor to carry out an investigation under the Rome Statute. ${ }^{34}$ There is no time limit related to the implementation of the preliminary examination, which depends on the circumstances and facts found in each different situation, after the process is conducted, ICC Prosecutor will decide whether to initiate an investigation if the information has been received is sufficient, conducts examinations and collects additional information if necessary, or refuses to carry out an investigation on the basis that there are no reasonable reasons to continue the investigation

\section{ICC'S JURISDICTION AND IMPACT OF STATE'S WITHDRAWAL}

\section{ICC's Jurisdiction}

The ICC is a permanent judicial institution that has the power to exercise jurisdiction over individuals who have committed the most serious crimes of concern to the international

31 International Criminal Court the Office of the Prosecutor, "Report on Preliminary Examination", Loc. Cit, p. 16.

32 International Criminal Court, "Statement of the Prosecutor of the International Criminal Court, Fatou Bensouda concerning the situation in the Republic of the Philippines", https://www.icccpi.int/Pages/item.aspx?name= 161013otp-stat-php, accessed on $14^{\text {th }}$ November 2019.

$33 \quad$ Ibid.

34 Ibid. 
community and have a complementary function to the national jurisdictions of countries. $^{35}$ The ICC aims to end impunity for perpetrators of international crimes and contribute to preventing these crimes from happening in the future. ${ }^{36}$

ICC is bound by certain jurisdictions and limitations in exercising its function and shall not try any case outside that jurisdiction. ICC's jurisdiction could be divided into: ${ }^{37}$

1) Personal jurisdiction. The ICC prosecutes individuals, not groups or States. Any individual who is alleged to have committed crimes within the jurisdiction of the ICC may be brought before the ICC. In fact, the Office of the Prosecutor's prosecutorial policy is to focus on those who, having regard to the evidence gathered, bear the greatest responsibility for the crimes, and does not take into account any official position that may be held by the alleged perpetrators. The Court shall have jurisdiction over natural persons pursuant to this Statute. ${ }^{38} \mathrm{~A}$ person who commits a crime within the jurisdiction of the Court shall be individually responsible and liable for punishment in accordance with this Statute. ${ }^{39}$

2) Material jurisdiction. The International Criminal Court ("the ICC" or "the Court") is a permanent international court established to investigate, prosecute and try individuals accused of committing the most serious crimes of concern to the international community as a

Article 1 of Rome Statute.

Preamble of Rome Statute.

International Criminal Court, "Understanding the International Criminal Court", https://www.icc- whole, namely the crime of genocide, crimes against humanity, war crimes and the crime of aggression. The jurisdiction of the Court shall be limited to the most serious crimes of concern to the international community as a whole. The Court has jurisdiction in accordance with this Statute with respect to the following crimes: (a) The crime of genocide; (b) Crimes against humanity; (c) War crimes; (d) The crime of aggression. ${ }^{40}$

3) Temporal jurisdiction. The ICC has jurisdiction only with respect to events which occurred after the entry into force of its Statute on 1 July 2002. If a State becomes a party to the Statute after its entry into force, the Court may exercise its jurisdiction only with respect to crimes committed after the entry into force of the Statute for that State, unless that State has made a declaration accepting the jurisdiction of the ICC retroactively. However, the Court cannot exercise jurisdiction with respect to events which occurred before 1 July 2002. For a new State Party, the Statute enters into force on the first day of the month after the 60th day following the date of the deposit of its instrument of ratification, acceptance, approval, or accession.

4) Territorial jurisdiction. The Court may exercise its jurisdiction in situations where the alleged perpetrator is a national of a State Party or where the crime

cpi.int/iccdocs/pids/publications/uicceng.pdf accessed on $14^{\text {th }}$ November 2019.

38 Article 25 (1) of Rome Statute.

39 Article 25 (2) of Rome Statute.

Article 5 of Rome Statute. 
was committed in the territory of a State Party.

In addition, to be eligible to try a case, ICC should fulfill the minimum threshold for the seriousness of a crime. ICC shall have the discretion to deny its jurisdiction in cases that do not fulfill the minimum requirement of crime seriousness, not only to ensure that the ICC limits its focus to the most serious crimes, but to manage ICC's caseload due to the limited resources it has. ${ }^{41}$ If the ICC handles every crime under its jurisdiction, including crimes with a lower seriousness or weight of crime, ICC will be inundated with cases that lead to ineffectiveness due to excessive and disproportionate workload. ${ }^{42}$

\section{ICC's Admissibility}

After assessing the crimes that fall under ICC's jurisdiction, another aspect of the crimes should also be considered is admissibility. The Rome Statute makes it clear that the ICC shall only exercise jurisdiction over:

a. A situation in which one or more crimes have been committed by reference or filed by a state party of the Rome Statute; ${ }^{43}$

b. A situation in which one or more crimes have been committed and are referred or filed by the UN Security Council acting under Chapter VII of the United Nations Charter; ${ }^{44}$ or

c. The ICC Prosecutor has started a proprio motu investigation based on the available information ${ }^{45}$

In the event that a case is initiated as stated in point (c), the ICC Prosecutor shall only initiate an investigation (and

41 S. SaCouto and K.A. Cleary, "The Gravity Threshold of the International Criminal Court", American Journal of International Law, Vol. 23, No. 5, 2008, p. 809.

42 M.M. El Zeidy, "The Gravity Threshold under the Statute of the International Criminal Court", Criminal Law Forum, Vol. 19, 2008, p. 36.

43 Article $13(a)$ of Rome Statute.

44 Article 13 (c) jo. Article 13 (b) of Rome Statute. preliminary examination) based on the information provided to the Office of Prosecutor (hereinafter referred to as OTP). ${ }^{46}$ This information could be obtained through an unlimited number of sources, for example from community organizations, NonGovernmental Organizations, Legal Aid Institutions, and other sources.

An assessment of issues of jurisdiction and admissibility is carried out in several stages of the judicial process at the ICC, including:

1) In the process of a preliminary examination by ICC Prosecutor to determine whether there are acceptable grounds for initiating an investigation; ${ }^{47}$

2) Pre Trial Chamber judges in authorizing the ICC prosecutor to carry out an investigation in a state of proprio motu by Pre Trial judges;

3) Pre Trial Chamber in issuing arrest orders and requests to appear before the trial by Pre Trial judges.

\section{Crime's Seriousness Related to Admissibility Principle}

The seriousness of a crime as an element that needs to be considered in determining ICC's acceptability and/or admissibility was introduced by Professor James Crawford at the ILC working group meeting which took place in May $1994 .{ }^{48}$ The idea aims to help the ICC regulate the caseload on available resources and prevent the ICC from being flooded by complaints or concerns involving petty crimes. The ICC was never intended to deal with every case that falls under its jurisdiction, but

$45 \quad$ Article 13 (b) jo. Article 15 of Rome Statute.

46 Otto Triffterer, The Rome Statute of the International Criminal Court: A Commentary, $3^{\text {rd }}$ Edition, Oxford: Hart Publishing, 2016, p. 731.

$47 \quad$ William A. Schabas, Op. cit, p. 465.

48 International Law Commission, "Summary Record of the $2356^{\text {th }}$ Meeting", 1994, p. 9. 
only resolves certain cases which have an adequate level of seriousness. ${ }^{49}$ Countries provide support for the ICC to only exercise its jurisdiction over cases that have sufficient international significance. ${ }^{50}$

The first application of the principle of the seriousness of a crime was found in the Lubanga Case, where the Pre Trial Chamber judge stated that there are two things that need to be considered in determining the seriousness of a crime, namely that the action that is the subject in the related case must be systematic or large-scale, and the fulfillment of the 'social alarm' element that arose in the international community as a result of this act. ${ }^{51}$ The panel of judges views that determining the seriousness of a crime was with the purpose of ensuring that the ICC only handled cases of the most influential high-ranking officials in the situation under investigation. ${ }^{52}$

The ICC Trial and Pre Trial Chamber judges show that the assessment of the seriousness of a crime depends very much on the policies of the ICC Prosecutors and court judges in the Chamber. However, a common practice that is publicly accepted in determining the seriousness of a crime including: $:^{53}$

a) The scale of the crimes committed (including assessments of geographic and temporal intensity); ${ }^{54}$

An assessment of the scale of a crime needs to consider the number of direct and indirect victims, the further damage caused by the crime, the physical and psychological harm to the victim and their family, and the

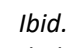

Pre-Trial Chamber I Decision on the Prosecutor's Application for Warrants of Arrest, Article 58, Situation in the Democratic Republic of the Congo, p. 21.

53 Pre-Trial Chamber II Decision Pursuant to Article 15 of the Rome Statute on the Authorization of an geographic and temporal spread of a crime (for example, a crime with high intensity in a short time or crime low over a long period).

b) The nature of the act against the law or the crime committed; 55 The nature of a crime can be judged on the basis of elements of each crime such as murder, rape and other crimes related to sexual and gender violence, crimes against minors, persecution, or restriction of the quality of life of a group that causes harm.

c) The method used to commit a criminal act; ${ }^{56}$ and

The manner of committing a crime can be judged based on the means used to commit the crime, the level of participation and intensity of the perpetrator, whether the crime was systematic and resulted from a plan, policy or abuse of power, elements of certain atrocities including the vulnerability of victims, the involvement of discrimination as a crime motive, or the use of rape and sexual violence as a way to destroy a group.

d) Impacts and losses incurred for victims and their families for the crimes committed. ${ }^{57}$

The impact of crime can be assessed based on the long-term suffering experienced by victims and increased vulnerability, perceived terror, and prolonged social, economic, and environmental impacts on a group.

Investigation into the Situation in the Republic of Kenya, p. 27.

54 Ibid.

55 Ibid.

56 Ibid., pp. $25-26$.

57 lbid, p. 26 


\section{ICC's Complementary Principle}

The ICC is only admissible to try the crimes that fall under its jurisdiction based on the principle of complementarity. The application of this principle aims to avoid conflicts that may occur between the ICC and the state that has the authority to try those crimes and as a form of guarantee for the jurisdiction and sovereignty that the state has over its own citizens and territories. ${ }^{58}$

The ICC shall not try a case in the case of:

1) The case is in the process of being investigated or prosecuted by the state which has jurisdiction over the case unless the state is unwillingness and/or unable to continue the investigation or prosecution; ${ }^{59}$

2) The case has been investigated by the state that has jurisdiction over the case and the state has decided not to prosecute the person concerned, unless the decision is the result of the state's unwillingness or inability to prosecute; ${ }^{60}$

3) The person concerned has been tried by the court for an act that is the subject of the crime, however, there are exceptions if the court is conducted on the grounds: ${ }^{61}$

a) To protect the person concerned from criminal responsibility for his actions which fall under the jurisdiction of the ICC; or

b) Trials are not conducted independently or are

58 Hilmi M. Zawati, "The International Criminal Court anf Complementarity", Journal of International Law and International Relations, Vol. 12, No. 1, 2016, p. 210.

59 Article 53 (1) point (a) - (c) of Rome Statute.

60 William A. Schabas, An Introduction to the International Criminal Court, Cambridge: Cambridge University Press, 2011, p. 294.

61 Ibid. impartial and do not conform to appropriate international legal norms of legal proceedings aimed at bringing the person concerned to trial.

Article 17 paragraph (1) of the Rome Statute describes the circumstances when a case cannot be accepted by the ICC on a complimentary basis, in which case the case is being investigated or prosecuted by the state that has jurisdiction over it or the case has been investigated and the country decided not to prosecute. Further the statement 'the case is being investigated' requires concrete and progressive evidence of the investigative steps that have been carried out by the state, including conducting interviews with witnesses and suspects, collecting evidence, or carrying out forensic analysis. ${ }^{62}$

The consideration of the complementarity principle in the Rome Statute is to balance the supranational power entrusted to the ICC in the power of national jurisdiction to provide assurance to the state that the state will retain ultimate power over its own judicial process and the ICC can only work with upholding the principle of complementarity. The ICC Prosecutor emphasized that the principle of complementarity represents the will of states parties to recognize the primary responsibility they have to exercise criminal jurisdiction. ${ }^{63}$ This principle is also based on the consideration of efficiency and effectiveness based on the fact that the state has the best

62 The Appeals Chamber Judgment on the appeal of Côte d'Ivoire against the decision of Pre-Trial Chamber I of 11 December 2014 entitled "Decision on Côte d'Ivoire's challenge to the admissibility of the case against Simone Gbagbo", Situation in the Republic of Côte D'ivoire in the Case of the Prosecutor v. Simone Gbagbo, p. 42

63 Paper on some Policy Issues before the Office of the Prosecutor 2003. 
access to evidence and witnesses to the crime. $^{64}$

The exercise of jurisdiction based on this principle aims to avoid conflicts that may occur between ICC and the state that has the authority to try these crimes due to its sovereignty and guarantee for the jurisdiction that the state has over its own citizens and territories. ${ }^{65}$

\section{STATE'S WITHDRAWAL FROM INTERNATIONAL TREATY}

\section{Based on VCLT 1969}

Based on the Vienna Convention on the Law of Treaties 1969 (hereinafter referred to as VCLT 1969), withdrawal as a party to an international treaty can be carried out solely based on the provisions of the international treaty or VCLT 1969. ${ }^{66}$

Most of the international treaties regulate the procedures for withdrawal or termination of the agreement at a certain time. in the case that the international treaty does not clearly regulate this matter, then termination of the treaty refers to the provisions contained in Article 65 to Article 68 of VCLT 1969 regarding the procedures to be followed. ${ }^{67}$

Invalidity, termination and/ or withdrawal as parties of international treaties or suspension of implementation of international treaties either as a result of the applicable convention or the provisions of these treaties may not interfere with the state's obligation to carry out obligations contained in international treaties which are subject to international law. ${ }^{68}$

64 Ibid.

65 Hilmi M. Zawati, "The International Criminal Court and Complementarity", Journal of International Law and International Relations, Vol. 12, No. 1, 2016, p. 210

66 Article 42 (2) of VCLT 1969.

67 Anthony Aust, "Modern Treaty Law and Practice 2nd ed.", Cambridge: Cambridge University Press, 2007, p. 277.
Withdrawal from an international treaty shall be carried out in accordance with procedures to prevent States from taking arbitrary actions. ${ }^{69}$ Parties intending to terminate, withdraw or postpone the implementation of an international treaty shall notify other parties with a written notification of withdrawal along with the reasons for withdrawal. ${ }^{70}$ Other parties shall be given no later than 3 months to respond to the withdrawal notification, except in terms of special urgency. ${ }^{71}$ If neither party objects within the notification period, the party wishes to terminate, resign or suspend the agreement may carry out the withdrawal process. If there are parties who raise objections, then the parties are required to find a solution through the process of negotiation, mediation, or arbitration even though these methods will not affect the rights and obligations of the parties under binding provisions. ${ }^{72}$

The impact of terminating an international treaty is regulated in Article 70 of VCLT 1969, which states that, unless stated otherwise in an international treaty or based on the agreement of the parties, termination of an international treaty shall:

a) relieve the parties from further obligation to enforce the treaty; and

b) does not affect the rights, obligations and legal circumstances of the parties bore of the implementation of the international treaty prior to its termination date.

The party that makes a resignation is freed from the obligations contained in the relevant international treaty

\footnotetext{
Article 43 of VCLT 1969.

Anthony Aust, Op. Cit., p. 63.

Article 65 (1) of VCLT 1969.

Article 65 (2) of VCLT 1969.

Article 65 (3) of VCLT 1969.
} 
when the withdrawal is considered valid or an entry into force. Before withdrawal is considered valid, the legal status, rights and obligations of the party making the withdrawal have not changed and do not affect the validity of the actions taken by that party. ${ }^{73}$

After the withdrawal entry into force, the party was considered as the third party of the international treaty (it was bounded into). Third parties are countries that are not parties to an international treaty. The position of the third party is described in Article 34 of VCLT 1969 which states that a treaty shall bear any obligations and rights for a third party without its consent. This article adheres to the principle of pacta tertiis nec nec nec prosunt, which stipulates that a third party might only be bound by the rights and obligations in a treaty if there is an agreement from that party. ${ }^{74}$ States parties od an international treaty shall not force a third party to comply with the law and obligations of the agreement it didn't enter into.

\section{Based on Rome Statute}

Rome Statute regulated withdrawal process in Article 127:

1) A State Party may, by written notification addressed to the Secretary-General of the United Nations, withdraw from this Statute. The withdrawal shall take effect one year after the date of receipt of the notification unless the notification specifies a later date.

2) A State shall not be discharged, by reason of its withdrawal, from the obligations arising from this Statute while it was a Party to the Statute, including any financial obligations which may have accrued. Its withdrawal shall not affect any

73 Mark Villiger, Commentary on the 1969 Vienna Convention on the Law of Treaties, Leiden: Martinus Nijhoff, 2009, p. 873. cooperation with the Court in connection with criminal investigations and proceedings in relation to which the withdrawing State had a duty to cooperate and which were commenced prior to the date on which the withdrawal became effective, nor shall it prejudice in any way the continued consideration of any matter which was already under consideration by the Court prior to the date on which the withdrawal became effective.

The withdrawal article in the Rome Statute opens up space for a state party to the statute to withdraw, either on its initiative or on the grounds that the state does not accept the amendment to the Rome Statute. Withdrawal may take place whenever the country feels the wish to withdraw. However, in the event that a state does not accept the amendment to the Rome Statute, the state party that does not accept the amendment can withdraw from the Rome Statute, and take effect immediately, but remain subject to Article 127 paragraph (2) of the Rome Statute, with notification of withdrawal of not more than one. years since the amendments to the Rome Statute became effective. ${ }^{75}$

3. Impact of State Withdrawal from ICC The withdrawal article in the Rome Statute opens up space for a state party to the statute to withdraw, either on its initiative or on the grounds that the state does not accept the amendment to the Rome Statute. Withdrawal might be made without any time limitation. However, in the event that a there are any amendment to the Rome Statute and state does not accept the amendment, the state party might withdraw from the Rome Statute, and

74 Malgosia Fitzmaurice, Third Parties and The Law of Treaties, Netherland: Kluwer Law International, 2002, p. 43.

75 Article 121 (6) of Rome Statute. 
take effect immediately, but remain subject to Article 127 paragraph (2) of the Rome Statute, with notification of withdrawal of not more than one years since the amendments to the Rome Statute became effective.

Article 127 paragraph (2) of the Rome Statute states that withdrawal cannot affect cooperation with the court in matters of criminal and judicial investigations that have started before the withdrawal of the state is deemed effective. The article is made with the possibility that the obligation to cooperate with the Court is blurred or unclear due to the complexity of the legal and factual circumstances, even though in fact a country can actually agree to cooperate voluntarily without being affected by the legal and factual circumstances that occur. ${ }^{76}$ This article also emphasizes that withdrawal cannot stop the process by withdrawing on the condition that there are considerations or prejudices that lead to the investigation process before withdrawal takes effect. ${ }^{77}$

\section{E. IMPACT OF PHILIPPINES' WITHDRAWAL ON ICC'S PRELIMINARY EXAMINATION AND INVESTIGATION}

The Philippines withdrew from the Rome Statute while the ICC Prosecutor was conducting a preliminary examination of suspected crimes against humanity in the Philippines related to the War on Drugs Operation since the presidency of Rodrigo Roa Duterte as Philippines' president in 2016. The paragraphs below will analyze how the Philippines' withdrawal affected the preliminary investigations being carried

76 Manisuli Senyonjo, "State Withdrawal Notifications from the Rome Statute of the International Criminal Court: South Africa, Burundi And The Gambia", Criminal Law Forum, 2018, p. 103.

77 Ibid.

78 Article 70 (2) jo. Article 70 (1) point (a) of VCLT 1969.

79 Mark E. Villiger, Commentary on the 1969 Vienna Convention on the Law of Treaties, Leiden: Martinus Nljhoff Publishers, 2009, p. 871. out by the ICC Prosecutor, particularly in fulfilling the seriousness of a crime both quantitatively and qualitatively. The analysis will begin with a description of the impact of the legal withdrawal of the Philippines from the Rome Statute which resulted in it being no longer bound by the provisions of the Rome Statute and creating temporal limits on the preliminary examination process being carried out by the ICC Prosecutor.

1. Impact of the Philippines' Withdrawal from the Rome Statute Under the VCLT 1969 and the Rome Statute

The withdrawal of the Philippines from the Rome Statute is bound by the withdrawal provisions in the 1969 VCLT as the law regulates international treaties in general and the Rome Statute as the law that regulates the provisions of withdrawal more specifically.

Withdrawal is a right for a state party that is bound by an international treaty. Article 70 paragraph (2) jo. Article 70 paragraph (1) point (a) of the 1969 VCLT states that withdrawal from an international treaty frees the parties from further obligations to enforce international treaties, ${ }^{78}$ with no retroactive effect. ${ }^{79}$

ICC Prosecutor announced the start of a preliminary investigation on a proprio motu basis for the alleged crimes against humanity committed by the Government of the Philippines on 8 February 2018. ${ }^{80}$ The Philippines then deposited the instrument of withdrawal from the Rome Statute to the Secretary General of the United Nations on 17 March $2018^{81}$ and based on Rome

80 International Criminal Court, "Statement of the Prosecutor of the International Criminal Court, Fatou Bensouda, on opening Preliminary Examinations into the situations in the Philippines and in Venezuela", Loc. Cit.

81 International Criminal Court The Office of the Prosecutor, "Report on Preliminary Examination Activities", 2018, p. 15 
Statute, the withdrawal shall entry into force one year from the deposit of the withdrawal instrument, ${ }^{82}$ namely on March 17, 2019.

As the state's withdrawal from an international treaty is entered into force, the state is now regarded as a third party to the treaty. However, it does not affect the rights, obligations or legal situation of the parties arising from the implementation of an international treaty prior to the withdrawal becoming effective or entered into force. ${ }^{83}$ The Rome Statute also regulates the same matter, with an additional explanation that explains that withdrawal from the Rome Statute shall not affect the financial obligations accrued and shall not affect any judgments or prejudices that the ICC had considered prior withdrawal was deemed effective. ${ }^{84}$ These considerations and prejudices shall be manifested in an act indicating this, for example by making a statement on the commencement of a preliminary examination which in the situation that occurred in the Philippines had been carried out by the ICC Prosecutor.

The preliminary examination initiated by the ICC indicated a prejudice or consideration of the situation in the Philippines related to the War on Drugs operation. As such, the Philippines' withdrawal from the Rome Statute does not eliminate the ICC's jurisdiction over the case being examined by the ICC Prosecutor when Philippines was still a party to the Rome Statute. The process of preliminary examinations and investigations carried out by the Prosecutor on any basis, whether on submissions by other countries, the UN Security Council, or on a proprio motu basis, cannot be stopped on the grounds that the state

Article 127 (1) of Rome Statute.

Article 70 (2) jo. Article 70 (1) point (b) of VCLT 1969. Article 127 (2) of Rome Statute. party withdraws from the Rome Statute. ${ }^{85}$

However, although the ICC might still allow exercise jurisdiction over cases that began before the Philippines withdrew from the Rome Statute, it is possible that the cases concerned cannot proceed to the next stage. Article 53 of the Rome Statute requires the ICC Prosecutor to consider certain criteria to determine whether the case has acceptable grounds for proceeding to the investigation stage. This consideration is made not only on the preliminary examination which starts on the basis of proprio motu, but also on the preliminary examination carried out based on the reference of the state party and the UN Security Council. The paragraphs below will analyze the criteria for admissibility of a case by the ICC Prosecutor and how the Philippines' withdrawal could threaten the fulfillment of these criteria and thus result in the inability to proceed with the preliminary hearing process which is continuing into the investigation stage.

2. The impact Philippines' Withdrawal from the Rome Statute on the ICC's Admissibility Principle

In the previous section, explained that the Philippines' withdrawal from the Rome Statute shall not eliminate the jurisdiction of the ICC to conduct preliminary examinations, investigations and trials of cases that occurred in the Philippines related to the War on Drugs Operation. However, it does not mean that the situation that is being examined by the ICC Prosecutor could continue to the investigation and trial process. The paragraph below will explain how the withdrawal by the Philippines affects the assessment of

85 Otto Trifterer, The Rome Statute of the International Criminal Court, A Commentary, $3^{\text {rd }}$ Edition, Jerman: Nomos Verlagsgesellschaft, 2013, p. 2322. 
the seriousness of a crime which may prevent the case from moving to the next stage.

In the preliminary examination process, the ICC Prosecutor needs to consider the factors contained in Article 53 paragraph (1) letters (a) to (c) of the Rome Statute before deciding whether there are any acceptable grounds for proceeding to the investigation stage, including :

1) Valid reason to believe that crimes falling within the jurisdiction of the ICC are or have been committed; ${ }^{86}$

The ICC Prosecutors' preliminary examination report in 2018 stated that the ICC Prosecutors have conducted a thorough factual and legal assessment of the information available to determine whether there is a reasonable basis to believe that crimes committed in the Philippines meet the ICC's material jurisdiction. ${ }^{87}$ The ICC Prosecutor stated that it had finalized an assessment of the material jurisdiction and would focus on an acceptability assessment which included an assessment of the complementarity and seriousness of a crime. ${ }^{88}$ Thus, the elements in Article 53 paragraph (1) letter (a) shall not become elements that might cause the crime that occurred in the Philippines to not proceed to the investigation stage.

2) The seriousness of a crime and the interests of the victim, and reasons to believe that the investigation is in line with the interest of justice, ${ }^{89}$

The following element is also known as interest of justice and the matter is entirely decided by ICC prosecutor's discretion. ${ }^{90}$

Related to this specific matter, ICC's Prosecutor pays attention to several aspects including the interests of the parties, including victims, organizations working with victims, and other parties affected by conflict such as states and parties trying to end the conflict. $^{91}$ Based on the reason that this element is the full authority of the ICC Prosecutor, the author cannot determine and carry out an analysis of the related elements.

3) The related case fulfills the element of admissibility; ${ }^{92}$

The admissibility principle could be found on article 17 of the Rome Statute, in determining some cases' admissibility, the following things shall be considered:

(a) The crime is being investigated or prosecuted by the state having jurisdiction over it, unless that country is unwilling or unable to proceed with the investigation or prosecution; ${ }^{93}$

(b) The crime has been investigated by the state that has jurisdiction over it and the state has decided not to continue prosecuting the suspect unless the decision is the result of the state's
Article 53 (1) point (a) of Rome Statute.

Report on Preliminary Examination Activities 2018, Op. Cit, p. 17.

Ibid, p. 64

Ibid.

90 Darryl Robinson, "Serving the Interests of Justice: Amnesties, Truth Commissions and the International
Criminal Court", European Journal of International Law, Vol. 14, No. 3, 2003, p. 487.

91 International Criminal Court The Office of the Prosecutor, "Policy Paper on the Interest of Justice", 2007, p. 9.

92 Article 53 (1) point (b) of Rome Statute.

93 Article 17 (1) point (a) of Rome Statute. 
unwillingness or inability to prosecute; ${ }^{94}$

(c) The perpetrator has been tried for the act which is the subject of the accusation, and the trial by the ICC cannot be carried out under Article 20 paragraph (3) of the Rome Statute; ${ }^{95}$

(d) The case concerned does not meet the seriousness threshold of a crime to justify further action by the ICC. ${ }^{96}$

Points (a) to point (c) above explain the reasons a case cannot be accepted based on the complementarity principle. Available information indicates that the Philippines has conducted and completed a number of investigations and prosecutions at the national level of certain perpetrators of crimes related to the War on Drugs Operation. ${ }^{97}$ In 2017, 3 PNP members were sentenced to 40 years in prison by the national court for the murder of a minor named Kian Delos Santos. ${ }^{98}$ However, the national judicial processes tend to only try the perpetrators of crimes who are the direct perpetrators. There is a tendency that these trials will create impunity for perpetrators of crimes that have occurred in the Philippines in highranking positions, such as the President, government officials, and commanders of the Philippines National Police. Thus, despite a number of prosecutions and trials under Philippines national law, it is still possible for the ICC to try these crimes because the existing trials are not conducted fairly and thoroughly for every perpetrator.

Article 17 (1) point (b) of Rome Statute

Article 17 (1) point (c) of Rome Statute.

Article 17 (1) point (d) of Rome Statute.

International Criminal Court The Office of the Prosecutor, "Report on Preliminary Examination Activities", 2019, p. 64.

98 Lian Buan, "Policeman guilty in Kian Delos Santos Killing", https://www.rappler.com/nation/217770-
Point (d) above explains why a case cannot be accepted on the grounds that the seriousness threshold of a crime is not met. The determination of the threshold for the seriousness of a crime in the Rome Statute reflects the will of Rome Statute negotiators that the ICC should focus on the most serious crimes worldwide. ${ }^{99}$

The factors that determine the ICC Prosecutor's assessment of the seriousness of a crime include quantitative and qualitative considerations assessed on the basis of: ${ }^{100}$

a) the scale of the crime committed;

b) the nature of the crime committed;

c) the method used to commit a criminal act; and

d) impacts and losses incurred for victims and their families for the crimes committed.

In practice, these four factors must be fulfilled cumulatively and not fulfilling one element can result in the seriousness of a crime being deemed not fulfilled.

3. Quantitative Admissibility Assessment Quantitative requirement of the seriousness of a crime might be assessed based on the scale of the impact and losses suffered by victims based on numerical data, including the number of direct and indirect victims, further damage caused by the crime, physical and psychological harm to the victim and their family, or the geographic and temporal spread of a crime (for example, a crime with high intensity over a short period of time or

caloocan-policemen-convicted-murder-kian-delossantos-killing, accessed on $21^{\text {st }}$ of September 2019.

99 Margaret M. de Guzman, "Gravity and the Legitimacy of the International Criminal Court", Fordham International Law Journal, Vol. 32, No. 5, 2008, p. 1431.

100 International Criminal Court The Office of the Prosecutor, Policy Paper on Case Selection and Prioritization, p. 12. 
low-intensity crimes over a long period of time). ${ }^{101}$

There is no defined or exact minimum number in the scale of crime to be able to meet the threshold of the seriousness of a crime. However, this figure must reflect grave crime that is of concern and / or concern to the international community as a whole as contained in the Preamble to the Rome Statute.

Looking at the cases that have occurred in the Philippines, the withdrawal by the Philippines will affect the scale of the crimes committed in connection with the War on Drugs Operation. There is no doubt that crimes committed while the Philippines were a party to the Rome Statute fall under the temporal jurisdiction of the ICC. The problem that then arises is on the crime that is committed by the Philippines government after the withdrawal and has resulted in a large number of victims. Most of the crimes committed by the Philippines government related to the War on Drugs Operation were murders that were not a continuous crime, so that with the enactment of the Philippines' withdrawal, these crimes will not fall under the jurisdiction of the ICC.

By the end of 2018, Philippines' citizens killed related to the War on Drugs Operation reached 12,000 people. ${ }^{102}$ These victims were killed as a result of being connected to the use or distribution of narcotics, mistaken identity, or as casualty victims in operations carried out by PNP members. ${ }^{103}$ This figure is the death toll for the War on Drugs Operation when the Philippines was still a party to the Rome Statute. On March 17, 2019, the

101 International Criminal Court The Office of the Prosecutor, Policy Paper on Preliminary Examination, p. 25.

102 Report on Preliminary Examination Activities 2018, Op. Cit, p. 16

103 Ibid.
Philippines' withdrawal from the Rome Statute became effective, and by that, Philippines no longer bound by the rights and obligations in the Rome Statute. At the end of 2019, independent non-governmental organizations and the Philippines National Commission on Human Rights estimated the number of victims of the War on Drugs Operation to reach $27,000 .^{104}$

As of 9 months after the withdrawal of the Philippines, the number of deaths as a result of the War on Drugs Operation reached 15,000 . This figure is significant to ignore and could greatly influence the scale of crimes committed by the Philippines. The number of Filipino citizens who have lost their lives is likely to continue to increase considering that Duterte's reign will continue until 2022.

Based on these facts, although the Rome Statute and its derivative regulations do not clearly stipulate the minimum figure in determining the adequacy or minimum threshold of the scale of the crime, the withdrawal of the Philippines will affect the tally of the number of victims in determining the seriousness of a crime which may allow a preliminary examination by the ICC Prosecutor can not continue to the next process.

4. Qualitative admissibility assessment Qualitative elements of the seriousness of a crime might be seen based on the nature of the crime committed, the method used to commit the crime, and the impact and losses incurred on the victim and his family for the crime committed. 
The ICC prosecutor has not formally issued a statement regarding the assessment of qualitative elements related to the case which is the focus of the preliminary examination of the Philippines case. The author believes that the withdrawal of the Philippines from the Rome Statute will have an impact on qualitatively assessing the seriousness of a crime, including in terms of:

a) The nature of the crimes committed; The crimes allegedly committed by the Philippines government are related to War on Drugs Operations is crimes against humanity which including murder, unlawful imprisonment, and violations of freedom of movement, torture and inhuman treatment, and rape. The assessment of the nature of crimes is carried out based on the fulfillment of elements of crimes against humanity committed, including 1) aimed at the civilian population; 2 ) part of group policy; and 3) systematic and widespread. In this case, the withdrawal of the Philippines might not affect the fulfillment of the nature of the crimes against humanity committed by the Philippines Government.

b) The method used to commit a criminal act;

The fulfillment of this element is assessed based on the methods used to commit crimes, the level of participation and intensity of the perpetrators, the implications of the systematic nature of a policy, the abuse of authority committed, and other matters related to the commission of the crime. The crimes that occurred in the Philippines were not only committed by the PNP, but there were allegations that the crimes were committed by hitmen who were instructed by PNP officials and state officials. The withdrawal by the Philippines will provide a temporary limit for the ICC to investigate crimes that fall under its jurisdiction, making it difficult to investigate the chain of command and involvement of Philippines government officials for crimes committed by hitmen after the withdrawal becomes effective. In this case, the withdrawal of the Philippines might affect the fulfillment of the elements of the methods used to commit criminal acts.

c) Impacts and losses incurred for victims and their families for the crimes committed.

Losses incurred as a result of crimes include material and immaterial losses. The assessment of the impact of losses carried out is directly proportional to the assessment of the number of victims who arise for the crimes committed. The limited material jurisdiction of the ICC to not be able to investigate noncontinuous crimes will affect the impact of the crimes committed. In this case, the withdrawal of the Philippines might affect the fulfillment of the elements of impact and loss that arise for the victim and his family for the crime committed. Based on the above analysis, the Philippines' withdrawal raises the possibility that the case being investigated by the ICC Prosecutor does not provide an acceptable basis for continuing the trial process to the next stage. The basis for the consideration that the preliminary examination cannot be continued is that the quantitative element in the form of the scale of the crime is not fulfilled and the qualitative element in the form of the method used to commit the crime and the effects and losses incurred for the victim and his family for the crime committed. 
Impact of Philippines' Withdrawal from International Criminal Court on Crime Against Humanity Investigation in Philippines

\section{F. CONCLUSION}

Although the ICC still has jurisdiction over crimes that occurred prior to the withdrawal of the Philippines, Philippines' withdrawal from Rome Statute increasing the possibility of the case become inadmissible and could not be carried out to the next stage of investigation and trial due to the admissibility requirement fulfillment, including in terms of the seriousness of a crime as regulated in the Article 53 paragraph (1) letter (b) of the Rome Statute. Philippines' withdrawal could result in the failure to fulfill the seriousness of a crime, whether assessed quantitatively because the victims of the non-continuing crimes committed after the withdrawal of the Philippines cannot be used as a basis for consideration by the ICC, nor can qualitative elements be fulfilled because withdrawal will result in the difficulty of investigating the involvement of the Philippines government in crimes committed by contract killers or hitmen on its command, and the inability to take into account the impact and losses incurred on victims and victims' families for crimes that did not continue after the withdrawal of the Philippines.

The regulation for withdrawal in the Rome Statute are tightened by amending the Rome Statute to make rules regarding the suspension of withdrawal by a state party in the event that a preliminary examination, investigation, trial or appeal process is being carried out at the ICC until a legally enforceable decision is made. This is done to prevent the withdrawal of the state party from being used as a form of avoiding the responsibility of individuals who commit international crimes.

The inclusion of explanations and minimum threshold for the assessment of the seriousness of a crime in The Rules of Procedure and Evidence as the instrument for the application of the Rome Statute to avoid inconsistencies in determining limits on the seriousness of a crime by ICC judges, both in the Pre Trial Chamber and the Trial Chamber.

\section{REFERENCES}

\section{Books}

Aust, Anthony, Modern Treaty Law and Practice, $2^{\text {nd }}$ Edition, Cambridge University Press, Cambridge, 2007.

Fitzmaurice, Malgosia, Third Parties and The Law of Treaties, Kluwer Law International, Netherland, 2002.

Kusumaatmadja, Mochtar dan Etty R. Agoes, Pengantar Hukum Internasional, PT. Alumni, Bandung, 2003.

Schabas, William A., An Introduction to the International Criminal Court, Cambridge University Press, Cambridge, 2011.

Triffterer, Otto, The Rome Statute of the International Criminal Court: A Commentary, 3rd Edition, Hart Publishing, Oxford, 2016.

Trifterer, Otto, The Rome Statute of the International Criminal Court: A Commentary, 3rd Edition, Nomos Verlagsgesellschaft, Germany, 2013.

Villiger, Mark E., Commentary on the 1969 Vienna Convention on the Law of Treaties, Martinus Nljhoff Publishers, Leiden, 2009.

Villiger, Mark, Commentary on the 1969 Vienna Convention on the Law of Treaties, Martinus Nijhoff, Leiden, 2009.

\section{Other Documents}

Bouwhuis, Stephen, "The International Law Commission's Definition of International Organizations", International Organizations Law Review, Vol. 9, No. 2, 2012. 
Buan, Lian, "Policeman guilty in Kian Delos Santos Killing", https://www.rappler.com/nation/21 7770-caloocan-policemen-convictedmurder-kian-delos-santos-killing.

Coalition for the International Criminal Court, "The Philippines' membership in the ICC comes to an end", https://www.coalitionfortheicc.org/n ews/20190315/philippines-leavesicc\#: :text=As\%20of\%2017\%20Marc h\%2C\%20the,and\%20the\%20crime\% 20of\%20aggression.

Coalition for the International Criminal Court, "Updates on Philippines", http://www.iccnow.org/index.php? mod=newsdetail\&news=267\&lang=e $\mathrm{n}$.

De Guzman, Margaret M., "Gravity and the Legitimacy of the International Criminal Court", Fordham International Law Journal, Vol. 32, No. 5, 2008.

International Criminal Court The Office of the Prosecutor, "Policy Paper on the Interest of Justice", 2007.

International Criminal Court The Office of the Prosecutor, "Policy Paper on Case Selection and Prioritization".

International Criminal Court The Office of the Prosecutor, "Policy Paper on Preliminary Examination".

International Criminal Court the Office of the Prosecutor, "Report on Preliminary Examination Activity", 2018.

International Criminal Court the Office of the Prosecutor, "Report on Preliminary Examination”, 2017.

International Criminal Court The Office of the Prosecutor, "Report on Preliminary Examination Activities", 2018.
International Criminal Court The Office of the Prosecutor, "Report on Preliminary Examination Activities", 2019.

International Criminal Court, "Statement of the Prosecutor of the International Criminal Court, Fatou Bensouda, on opening Preliminary Examinations into the situations in the Philippines and in Venezuela", https://www.icccpi.int/Pages/item.as px? name $=180208$-otp-stat.

International Criminal Court, "Statement of the Prosecutor of the International Criminal Court, Fatou Bensouda concerning the situation in the Republic of the Philippines", https://www.icc-

cpi.int/Pages/item.aspx?name= 161013otp-stat-php.

International Criminal Court, "The Philippines Becomes the 117th State to Join the Rome Statute System", https://asp.icc-

cpi.int/en_menus/asp/press\%20rele ases/press\%20releases\%202011/Pag es /pr717.aspx.

International Criminal Court, "Understanding the International Criminal Court", https://www.icccpi.int/iccdocs/pids/publications/uicc eng.pdf.

International Law Commission, "Summary Record of the 2356th Meeting", 1994. Johnson, David T., "Governing through Killing: The War on Drugs in the Philippines", Asian Journal of Law and Society, Vol. 5, 2018.

Ocampo, Rosanna and Laila Matar, "Philippines: UN Action Offered a Glimpse of Hope and Justice", https://www.amnesty.org/en/latest/ 
Impact of Philippines' Withdrawal from International Criminal Court on Crime Against

Humanity Investigation in Philippines

news/2019/08/philippines-un-actionoffered-glimpse-hope-justice/.

Ocampo, Rosanna and Laila Matar, "Philippines: UN Action Offered a Glimpse of Hope and Justice", https://www.amnesty.org/en/latest/ news/2019/08/philippines-un-actionoffered-glimpse-hope-justice/.

Opinio Juris, "The Departed: Implications of the Philippines' Withdrawal from the ICC",

http://opiniojuris.org/2018/04/12/th e-departed-implications-of-thephilippines-withdrawal-fromthe-icc/. Paper on some Policy Issues before the Office of the Prosecutor 2003.

Philippine Drug Enforcement Agency 2014 Annual Report.

Philippine Drug Enforcement Agency 2015 Annual Report.

Pre-Trial Chamber I Decision on the Prosecutor's Application for Warrants of Arrest, Situation in the Democratic Republic of the Congo.

Pre-Trial Chamber II Decision Pursuant to Article 15 of the Rome Statute on the Authorization of an Investigation into the Situation in the Republic of Kenya.

Reyes, Danilo Andres, "The Spectacle of Violence in Duterte's "War on Drugs"'", Journal of Current Southeast Asian Affairs, Vol. 35, 2016.

Robinson, Darryl, "Serving the Interests of Justice: Amnesties, Truth Commissions and the International Criminal Court", European Journal of International Law, Vol. 14, No. 3, 2003.

SaCouto, S. and K.A. Cleary, "The Gravity Threshold of the International Criminal Court", American Journal of International Law, Vol. 23, No. 5, 2008.
Sari, Indah, "Kejahatan-Kejahatan Internasional (International Criminal Law) Dan Peranan International Criminal Court (ICC) Dalam Penegakan Hukum Pidana Internasional", Jurnal IImiah Hukum Dirgantara - Fakultas Hukum Universitas Suryadarma, Vol. 6, No. 1, 2015.

Sarlina, Veniati, "Respon Amnesty Internasional Terhadap Pemberantasan Narkotika dan Obat Obatan Berbahaya (Narkoba) di Filipina pada Masa Rodrigo Duterte", eJournal Ilmu Hubungan Internasional, 2018.

Senyonjo, Manisuli, "State Withdrawal Notifications from the Rome Statute of the International Criminal Court: South Africa, Burundi And The Gambia", Criminal Law Forum, 2018.

Suwardi, Sri Setianingsih, "Beberapa Catatan Mahkamah Pidana Internasional (International Criminal Court) Dalam Kaitannya dengan Perserikatan Bangsa- Bangsa (PBB)", Jurnal Hukum dan Pembangunan, No. 4, 2017, p. 447.

UN Handbook on Final Clause of Multilateral Treaties.

Zawati, Hilmi M., "The International Criminal Court anf Complementarity", Journal of International Law and International Relations, Vol. 12, No. 1, 2016.

Zeidy, M.M. El, "The Gravity Threshold under the Statute of the International Criminal Court", Criminal Law Forum, Vol. 19, 2008.

\section{Legal Documents}

Rome Statute of the International Criminal Court 1998. 
The Appeals Chamber Judgment on the appeal of Côte d'Ivoire against the decision of Pre-Trial Chamber I of 11 December 2014 entitled "Decision on Côte d'Ivoire's challenge to the admissibility of the case against
Simone Gbagbo", Situation in the Republic of Côte D'ivoire in the Case of the Prosecutor v. Simone Gbagbo.

Vienna Convention on the Law of Treaties (VCLT) 1969. 